\title{
Gambaran Status Karies Berdasarkan Indeks DMF-T dan Indeks PUFA pada Orang Papua di Asrama Cendrawasih Kota Manado
}

\author{
Fernando B. Jotlely \\ Vonny N. S. Wowor \\ Paulina N. Gunawan \\ ${ }^{2}$ Program Studi Pendidikan Dokter Gigi Fakultas Kedokteran
Universitas Sam Ratulangi Manado
Email: jotlelyfernando@yahoo.com
}

\begin{abstract}
Caries is one of the dental and oral health problems in Indonesia. Caries is a multifactorial disease, mainly caused by the lack of awareness to keep and maintain dental health. Papuan people are more likely to use areca nuts to clean their teeth instead of brushing their teeth in correct order. This study was aimed to obtain the caries index among Papuan people who lived in Manado based on DMF-T index and PUFA index. This was a descriptive study with a cross-sectional design conducted at Asrama Cendrawasih in Manado. There were 114 Papuan people as the study population. Subjects were 54 Papuan people (males and females) obtained by using purposive sampling method. The results showed that the average DMF-T indexes were 5 in males and 5.9 in females. Based on the average index of DMF-T (5.3), the caries status was categorized as high. Additionally, the untreated caries status had PUFA index of 0.3; in both sexes the average index was 0.3. Conclusion: Based on DMF-T index and PUFA index, the caries status of Papuan people at Asrama Cendrawasih Manado was categorized as high.
\end{abstract}

Keywords: caries, PUFA index, DMF-T index

\begin{abstract}
Abstrak: Karies merupakan salah satu masalah kesehatan gigi dan mulut di Indonesia. Karies disebabkan oleh beberapa factor, antara lain kurangnya kesadaran tentang kebersihan gigi dan mulut. Masyarakat Papua lebih mengutamakan menggunakan pinang sebagai bagian dan rutinitas membersihkan rongga mulut dibanding menyikat gigi dengan baik dan benar. Penelitian ini bertujuan untuk mengetahui tingkat karies gigi pada orang Papua yang ada di kota Manado berdasarkan indeks DMF-T dan indeks PUFA. Jenis penelitian ialah deskriptif dengan desain potong lintang. Populasi penelitian di Asrama Cendrawasih di Kota Manado berjumlah 114 orang Papua. Subyek penelitian sebanyak 54 orang Papua, diperoleh dengan menggunakan purposive sampling method. Hasil penelitian memperlihatkan rerata indeks DMF-T pada laki-laki sebesar 5 dan pada perempuan sebesar 5,9. Berdasarkan rerata indeks DMF-T sebesar 5,3 status karies subyek penelitian termasuk kategori tinggi. Status karies yang tidak dirawat pada subyek penelitian berdasarkan indeks PUFA sebesar 0,3 dengan rerata pada laki-laki dan perempuan masing-masing sebesar 0,3. Simpulan: Berdasarkan indeks DMF-T dan indeks PUFA, status karies pada orang Papua di Asrama Cendrawasih Kota Manado termasuk kategori tinggi.
\end{abstract}

Kata kunci: karies, indeks PUFA, indeks DMF -T

Gigi merupakan salah satu organ tubuh yang penting bagi fungsi pengunyahan, bicara, dan fungsi estetik atau penampilan. Seiring bertambahnya usia seseorang, gigi yang ada rentan terhadap berbagai gangguan atau masalah. Salah satu masalah yang sering terjadi pada gigi-geligi ialah masalah gigi berlubang atau karies gigi. 
Karies gigi merupakan suatu penyakit jaringan keras gigi yang terjadi pada email, dentin, dan sementum, bersifat penyakit kronis yang paling sering memengaruhi individu pada segala usia. ${ }^{1}$ Penyakit ini merupakan masalah oral yang jika tidak ditangani akan menyebabkan kerusakan total pada gigi yang sakit. ${ }^{2}$

Data Riset Kesehatan Dasar (Riskesdas) Tahun 2013 menunjukkan peningkatan persentase prevalensi karies aktif pada penduduk Indonesia yakni sebesar 43,4\% pada tahun 2007 meningkat menjadi $53,2 \%$ pada tahun $2013 .^{3}$ Indeks DMF-T menggambarkan tingkat pengalaman kerusakan gigi atau karies. Indeks DMF-T merupakan penjumlahan dari gigi berlubang, gigi yang hilang, dan gigi yang ditambal. Prevalensi karies yang diukur berdasarkan indeks DMF-T rata-rata sebesar $4,6 .^{3}$

Data tentang karies yang diperoleh selama ini umumnya menggambarkan tentang pengalaman karies. Data tentang gambaran tingkat keparahan karies yang tidak tertangani yang dialami individu jarang tersedia, padahal data ini penting untuk bahan evaluasi dan perencanaan bagi pemerintah dalam penanggulangan penyakit karies. Karies yang tidak dirawat dapat menimbulkan kerusakan atau akibat yang lebih parah seperti pulpitis, ulserasi, fistula, abses. Indeks yang digunakan untuk menghitung keparahan karies gigi yang tidak dirawat dikenal sebagai indeks PUFA. Pada gigi permanen, indeks ini ditulis dengan menggunakan huruf kapital (PUFA) sedangkan pada gigi susu ditulis menggunakan huruf kecil (pufa). ${ }^{4}$

Indonesia memiliki beranekaragam suku bangsa, salah satu di antaranya yaitu suku Papua. Papua merupakan wilayah provinsi yang terletak di paling timur Indonesia, yang memiliki banyak suku di dalamnya. Berdasarkan data Riskesdas tahun 2013, data indeks DMF-T provinsi Papua dan Papua Barat sebesar 5,7. ${ }^{3}$ Dari data Riskesdas tersebut dapat dilihat bahwa angka prevalensi karies yang terjadi di Papua masih tinggi. Hal ini dikarenakan faktor kurangnya pengetahuan masyarakat yang ada di Papua tentang pentingnya menjaga kebersihan gigi dan mulut.

Faktor perilaku masyarakat Papua yang dijadikan suatu budaya atau kebiasaan antara lain masih memercayai hal-hal yang berkaitan dengan adat seperti mengunyah pinang untuk kebersihan gigi, padahal mengunyah pinang dapat menyebabkan penumpukan karang gigi yang nanti akan menjadi karies. Masih sedikitnya kesadaran untuk memeriksa gigi di klinik gigi dan mengakibatkan cukup banyak tingkat karies yang terjadi di Papua. Selain faktor pengetahuan dan perilaku di atas ada pula faktor yang sangat mendukung yakni, faktor sosial ekonomi dan tingkat sumber daya manusia di bidang kesehatan masih kurang.

Berdasarkan uraian tersebut, peneliti tertarik melakukan penelitian ini untuk mendapatkan gambaran status karies pada orang Papua yang berdomisili di Kota Manado karena sampai saat ini masih kurangnya data statistik yang memadai mengenai indeks DMF-T dan PUFA pada orang Papua yang ada di kota Manado.

\section{BAHAN DAN METODE}

Jenis penelitian ini ialah deskriptif dengan desain potong lintang. Penelitian dilakukan di Asrama Cendrawasih Papua yang terdapat di Manado pada bulan April Mei 2017. Populasi dalam penelitian ini ialah orang asli Papua yang tinggal di Asrama Cendrawasih Papua Manado berjumlah 114 orang berusia 18-25 tahun. Besar sampel penelitian ditentukan dengan menggunakan rumus Slovin dan diperoleh 54 subyek penelitian melalui purposive sampling method. Dalam penelitian ini digunakan dua indeks yaitu DMF-T dan PUFA.

\section{HASIL PENELITIAN}

Penelitian dilakukan di Asrama Cendrawasih Manado yang berlokasi di Batu Kota dengan penghuni sebanyak 114 orang terdiri dari 80 orang laki-laki dan 34 orang perempuan yang berasal dari berbagai provinsi di Papua.

Karakteristik subjek penelitian berda- 
sarkan jenis kelamin terdiri dari 37 orang laki-laki $(68,5 \%)$ dan 17 orang perempuan $(31,5 \%)$. Distribusi subyek berdasarkan kelompok usia mendapatkan terbanyak pada kelompok usia 22-23 tahun (40,7\%) (Tabel 1).

Tabel 2 memperlihatkan rerata indeks DMF-T subyek penelitian dengan hasil 5,3 yang tergolong dalam kriteria tinggi. Pada laki-laki didapatkan rerata sebesar 5 dan pada perempuan rerata sebesar 5,9. Tabel 3 memperlihatkan status karies yang tidak dirawat pada subyek penelitian berdasarkan indeks PUFA sebesar 0,3 dengan rerata pada laki-laki dan perempuan masingmasing sebesar 0,3.

Tabel 1. Distribusi karakteristik subjek penelitian berdasarkan kelompok usia

\begin{tabular}{ccccc}
\hline $\begin{array}{c}\text { Usia } \\
\text { (tahun) }\end{array}$ & Laki - laki & Perempuan & n & $\begin{array}{c}\text { Persentase } \\
(\boldsymbol{\%})\end{array}$ \\
\hline $18-19$ & 8 & 1 & 9 & 16,7 \\
$20-21$ & 9 & 2 & 11 & 20,4 \\
$22-23$ & 14 & 8 & 22 & 40,7 \\
$24-25$ & 6 & 6 & 12 & 22,2 \\
Jumlah & 37 & 17 & 54 & 100 \\
\hline
\end{tabular}

Tabel 2. Rerata indeks DMF-T subyek penelitian

\begin{tabular}{ccccccc}
\hline $\begin{array}{c}\boldsymbol{\Sigma} \mathbf{n} \\
(J u m l a h \text { subyek) }\end{array}$ & $\boldsymbol{\Sigma D}$ & $\boldsymbol{\Sigma M}$ & $\boldsymbol{\Sigma} \mathbf{F}$ & $\begin{array}{c}\text { DMF-T } \\
(\mathbf{\Sigma D}+\mathbf{M}+\mathbf{F})\end{array}$ & $\begin{array}{c}\text { DMF-T } \\
\text { rerata }\end{array}$ & Kriteria \\
\hline 54 & 274 & 8 & 3 & 285 & 5,3 & Tinggi \\
\hline
\end{tabular}

Tabel 3. Rerata indeks PUFA subyek penelitian

\begin{tabular}{ccccccc}
\hline $\begin{array}{c}\boldsymbol{\Sigma} \mathbf{n} \\
(\mathbf{J u m l a h} \text { subyek) }\end{array}$ & $\boldsymbol{\Sigma P}$ & $\boldsymbol{\Sigma U}$ & $\boldsymbol{\Sigma} \mathbf{F}$ & $\boldsymbol{\Sigma A}$ & $\begin{array}{c}\text { PUFA } \\
(\mathbf{P}+\mathbf{U}+\mathbf{F}+\mathbf{A})\end{array}$ & $\begin{array}{c}\text { PUFA } \\
\text { rerata }\end{array}$ \\
54 & 5 & 10 & 0 & 0 & 15 & 0,3 \\
\hline
\end{tabular}

\section{BAHASAN}

Pengukuran pengalaman karies gigi berdasarkan indeks DMF-T pada orang Papua di Kota Manado telah dilakukan sebelumnya oleh Uamang et al. ${ }^{5}$ dengan hasil DMF-T rerata sebesar 5,9\% dari 45 orang responden. Penelitian ini juga mengukur indeks DMF-T dengan karakteristik responden penelitian berdasarkan usia dan jenis kelamin. Orang asli Papua yang tinggal di Asrama Cendrawasih, berusia 18-25 tahun dan yang berjenis kelamin perempuan lebih sedikit dibandingkan dengan yang berjenis kelamin laki-laki. Hasil pemeriksaan status karies pada subyek penelitian didapatkan rerata 5,3 yang tergolong dalam kategori tinggi. Pada penelitian ini ditemukan seluruh orang asli
Papua yang ada di Asrama Cendrawasih memiliki karies gigi. Hasil penelitian ini tidak jauh berbeda dengan hasil penelitian Yulineri et al. ${ }^{6}$ yang melaporkan bahwa orang yang mengonsumsi pinang secara berlebihan akan lebih berisiko mengalami karies gigi.

Tingginya tingkat karies gigi dapat disebabkan oleh beberapa faktor antara lain kurangnya pengetahuan perilaku menjaga kebersihan gigi dan mulut yang diketahui dengan banyaknya pertanyaan dari subyek penelitian saat penelitian berlangsung. Permukaan gigi yang tidak disikat dengan benar akan menyebabkan sisa makanan menumpuk dan menimbulkan tumpukan plak yang akan memperparah karies yang terjadi. ${ }^{7}$ Berdasarkan jenis kelamin, pada 
kategori persentase penyakit karies gigi lebih besar pada subjek dengan jenis kelamin laki-laki yaitu $68,5 \%$ sedangkan pada perempuan $31,5 \%$. Pada penelitian ini pemeriksaan indeks DMF-T yang paling banyak ditemukan yaitu komponen D (decay) atau gigi yang mengalami karies dibandingkan komponen $\mathrm{M}$ (missing) atau kehilangan gigi dan $\mathrm{F}$ (Filling) atau gigi yang ditambal. Hasil penelitian ini dapat dipengaruhi oleh tingkat kesadaran untuk menjaga kebersihan gigi dan mulut lebih besar pada perempuan dari pada laki-laki. Hasil ini sesuai dengan penelitian status keparahan karies gigi di Kabupaten Donggala oleh Namora et al. $^{8}$ yang mendapatkan bahwa perempuan lebih memperhatikan penampilannya sehingga kesadaran menjaga kebersihan gigi dan mulut lebih tinggi dan tingkat karies lebih rendah, sedangkan laki-laki cenderung kurang memperhatikan penampilannya.

Hasil pemeriksaan indeks PUFA memperlihatkan bahwa perempuan mengalami pulpitis sebanyak 5 dan pada laki-laki mengalami ulser sebanyak 10. Hal ini sesuai dengan teori yang dijelaskan oleh Volker dan Russel bahwa prevalensi karies gigi pada perempuan lebih tinggi dibanding laki-laki karena erupsi gigi pada perempuan lebih cepat dibanding laki-laki sehingga gigi tetap perempuan lebih lama berhubungan dengan faktor terjadinya karies. ${ }^{9}$ Pulpitis yang kemudian menjadi lebih parah hingga menyebabkan ulserasi yang terjadi pada gigi geligi juga tidak terlepas dari kesadaran menjaga dan merawat kesehatan rongga mulut. Berdasarkan Riskesdas tahun 2013, masyarakat Papua memiliki tingkat kesadaran menyikat gigi yang paling rendah di Indonesia yaitu hanya sebesar 49,6\%. Proporsi penduduk yang berobat ke dokter gigi untuk masyarakat Papua misalnya dengan menambal gigi yang sudah berlubang atau mencabut gigi yang derajat kariesnya sudah besar agar tidak ada ulserasi disekitar jaringan lunaknya masih minim yaitu hanya sebesar 36\%. Padahal tindakan-tindakan untuk pencegahan ini diperlukan untuk memperbaiki derajat kesehatan gigi dan mulut masyarakat Papua terlepas dari lokasi tempat tinggalnya. ${ }^{3}$

Menurut Tebai, ${ }^{10}$ indeks DMF-T pada orang Papua di Asrama Cilaki Kota Bandung termasuk kategori tinggi. Hal ini disebabkan karena kurangnya kepedulian responden untuk memeriksa kesehatan gigi dan mulut, dengan melakukan perawatan berupa penambalan sehingga menyebabkan karies menjadi parah. Pola seperti juga yang terdapat pada orang Papua yang ada di Kota Manado, yang kurang kepeduliannya untuk melakukan perawatan terhadap karies. ${ }^{10}$

Selain faktor kurangnya kesadaran orang Papua untuk pergi ke klinik gigi dan melakukan perawatan, terdapat juga faktor ekonomi. Ekonomi pada orang Papua yang menengah ke bawah tidak menjadikan perawatan kebersihan gigi dan mulut sebagai prioritas, karena berpikir masih banyak yang lebih penting daripada sekedar melakukan tindakan terhadap gigi. ${ }^{11}$ Faktor pengetahuan orang tua seharusnya mengajarkan tentang cara menyikat gigi yang baik dan benar dan menganjurkan untuk merawat kebersihan gigi dan mulut. Masih kurangnya penyuluhan mengenai kesehatan gigi dan mulut pada orang tua yang ada di Papua sehingga orang tua juga kurang menghimbau dan mengajarkan memelihara kesehatan gigi dan mulut pada anaknya. ${ }^{12}$

\section{SIMPULAN}

Status karies berdasarkan indeks DMF$\mathrm{T}$ dan indeks PUFA pada orang Papua di Asrama Cendrawasih Kota Manado termasuk kategori tinggi.

\section{SARAN}

Perlu dilakukan penelitian lebih lanjut untuk membandingkan gambaran status karies berdasarkan indeks DMF-T dan indeks PUFA pada orang Papua dan orang non-Papua.

Disarankan bagi pemerintah untuk lebih memperhatikan keadaan gigi dan mulut pada orang Papua antara lain dengan menular luaskan penyuluhan dan peningkatan fasilitas kesehatan khususnya kesehatan gigi dan mulut. 


\section{DAFTAR PUSTAKA}

1. Pintauli S, Hamada T. Menuju Gigi dan Mulut Sehat. Medan: USU Press, 2009; p. 4-24.

2. Solikin. Hubungan tingkat pengetahuan orang tua tentang kesehatan gigi dan mulut dengan kejadian karies gigi pada anak prasekolah di TK 01 Pertiwi Karangbangun Karanganyar [Skripsi]. Surakarta: Program Studi Ilmu Keperawatan. Fakultas Ilmu Kesehatan. Universitas Muhamadiyah Surakarta; 2013.

3. Riset Kesehatan Dasar. Badan Penelitian dan Pengembangan Kesehatan Departemen Kesehatan, Republik Indonesia. Jakarta; Laporan Nasional, 2013; p. 110-19.
4. Monse B, Heinrich-Weltzien R, Benzian H, Holmgren C, van Palenstein HW. PUFA - An index of clinical consequences of untreated dental caries. Comm Dent Oral Epidemiol; 2010;38:77-82.

5. Uamang S. Gambaran status karies gigi pada mahasiswa asal Kabupaten Mimika yang mempunyai kebiasaan menyirih di Manado. eG. 2017;5(1):47-52.

6. Yulianti RP, Muhlisin A. Hubungan antara pengetahuan orang tua tentang kesehatan gigi dan mulut dengan kejadian karies gigi pada anak di SDN Karanganyar. 2012. p. 25-30. Available from: eprints.ums.ac.id/14779/1/ HALAMAN_DEPAN.pdf 